\title{
Evaluation of Incubation Yield, Vaccine Response, and Performance of Broilers Submitted to In-Ovo Vaccination at Different Embryonic Ages
}

\section{-Author(s)}

\section{Fernandes JIM \\ Prokoski K' \\ Oliveira $\mathrm{BC}$ \\ Oro CS' \\ Oro PJ" \\ Fernandes NLM"II}

\begin{abstract}
Laboratory of Poultry Experimentation Federal University of Paraná - Palotina, 85950-000, Paraná, Brazil.

" Poultry production supervisor, Cvale Company, Palotina, 85950-000, Paraná, Brazil

III Department of Veterinary Science, Federal University of Paraná - Palotina, 85950-000, Parana, Brazil.
\end{abstract}

\begin{abstract}
The aim of this study was to evaluate the effects of in-ovo vaccination on different incubation days of broiler embryos derived from young and old breeders on incubation indexes, vaccine response, and broiler performance. A number of 20,160 fertile eggs was distributed according to a completely randomized design in a $4 \times 2$ factorial arrangement (inovo vaccination on $16,17,18$, or 19 days of incubation, and breeders of 31 or 52 weeks of age), totaling eight treatments with 15 replicates of 168 eggs each. Vaccination procedures and vaccines (strains and doses) were those routinely applied in commercial hatcheries. After hatch, 960 male chicks were housed and distributed according to the same experimental design previously applied in the hatchery. There were hatching losses $(p<0.05)$ when eggs were vaccinated before 18 days of incubation. Greater Marek's disease antibody titers were obtained when the in-ovo vaccination was performed on day 19 of incubation, regardless breeder age. Embryonic age at vaccination did not compromise broiler performance in the field, and the flexibility of embryonic age for in-ovo vaccination can reduces incubation costs.
\end{abstract}

\section{INTRODUCTION}

Vaccination is an essential tool for the control of several diseases and for the maintenance of good health status of broiler flocks. However, inducing optimal and protective levels of humoral and/or cellular immune responses require several days following vaccination. In-ovo vaccination is therefore proposed to stimulate an early immune response in young chicks broiler embryos are routinely vaccinated in ovo between days 17.5 and 19.25 of incubation, directly in the amniotic fluid or in the embryo's body. The antigens are retained by the embryo, which starts to develop the immune response against these antigens. The technology of in-ovo vaccination was introduced over three decades ago, and it is currently applied in more than $90 \%$ of the commercial hatcheries in the United States (Berchieri \& Bolis, 2003; Oliveira, 2013).

In-ovo vaccination contributes to reduce the "susceptible window" between vaccination and early exposure to infectious agents, in comparison withpost-hatching vaccination (Negash et al., 2004). Birds already develop certain immune functions before hatching, and in-ovo vaccination stimulates both innate and adaptive immune responses. Thus, in-ovo vaccinated chicks develop a considerable degree of protection during incubation (Negash et al., 2004; Williams \& Zedek, 2010).

The in-ovo vaccination technique allows eggs to be evenly vaccinated, induces early immune response to vaccines, reduces the stressful responses associated with post-hatching procedures, provides precise inoculation, reduces contamination, as well as application of 
Fernandes JIM, Prokoski K, Oliveira BC, Oro CS, Oro PJ, Fernandes NLM
Evaluation of Incubation Yield, Vaccine Response, and Performance of Broilers Submitted to In-Ovo Vaccination at Different Embryonic Ages other biological materials that may influence broiler performance (Edens, 1999). However, factors such as embryonic age at vaccination, vaccination site, aseptic vaccine preparation, hatchery hygiene, and sanitization of the in-ovo vaccination equipment may affect the efficiency of this technique (Avakian et al. 2002; Willians \& Zetec, 2010).

Automation also brings certain advantages to the operability of a hatchery in terms of separation of embryonated from infertile eggs, as well as reduces time between hatching and placementon the farm (Willians \& Zetec, 2010).

Despite these several advantages, literature reports little technical information on the interactions of factors that may influence the expected automation results. However, poultry companies seldom disclose information on this issue. Therefore, obtaining scientific data may lead to the development of the techniques applied, and is extremely important considering the sheer volume of eggs that are vaccinated annually. In Brazil, in-ovo vaccination started to be applied in 1999, and in 2001, more than 100 million eggs/year were vaccinated. In 2011, this number was around 3.3 billion, and considering that 6.2 billion chicks hatched in 2014, the number of vaccinated eggs last year is estimated to be around 4 billion (Oliveira, 2013; Avisite, 2014).

Between 17.5 and 19.25 days of incubation, eggs are transferred to the hatchers and chicks are vaccinated in ovo. Although this is an automated process, in-ovo vaccination still requires labor and may be applied on Sundays and holidays, which labor costs due to overtime payment or layoffs on working days. Moreover, it is difficult to find workers that are able to work on these dates, and this affects their motivation and commitment to their duties. Anticipating or delaying vaccination may reduce the costs of the incubation process, but on the other hand, may result in worse hatchery performance. Ricks et al. (1999) reported a decrease in hatchability around $1 \%$, on average, in commercial hatcheries when vaccinations were performed on day 17 of incubation in several experiments.

On the other hand, can breeder age, and consequently the position of the embryo in the egg, influence embryonic age at the time of in-ovo vaccination? It is known that breeder age is correlated with egg size (Abudabos, 2010). Eggs from young broiler breeders, in the beginning of their production cycle, are smaller, lower yolk content, and thicker albumen that those of older breeders, and therefore, yield smaller chicks at hatch; however, as breeders age, their eggs become larger, generating larger chicks at hatch. Therefore, breeder age may influence the determination of the time of in-ovo vaccination.

The technique used for the administration of inovo vaccines is critical. Delivering the vaccine in an incorrect location may resultin ineffective vaccination, thus reducing its benefits. For instance, it was observed that vaccine deposition into the air cell or allantoic fluid did not provide adequate protection of chicks against subsequent Marek's disease viral challenge (Williams \& Hopkins, 2011). At the time of vaccination, the embryo should be in the hatching position, with the head under the right wing, the yolk sac should be completely absorbed. Injections after day 19 of incubation may injurethe embryo, resulting in mortality. On the other hand, vaccinations at an earlier age may increase the risk of contamination, compromising the livability and quality of the chicks at hatch (Berchieri Jr \& Bolis, 2003).

In addition to these questions, perhaps the one with the most impact is: can the embryonic age at the time of in-ovo vaccination affect the immune response and the performance of the offspring? The success of vaccination programs depends on the capacity of birds to establish an immune response after vaccination, and changing the day of in-ovo vaccination may compromise their capacity to respond to antigens, consequently affecting their development and production efficiency.

In order to answer these questions, two experiments were conducted, aiming at evaluating the effects of inovo vaccination at different embryonic ages $(16,17$, 18, and 19 days of incubation) and breeder age (31 and 52 weeks) on hatchability, embryonic mortality, culling, vaccine response, and performance of broilers at slaughter age.

\section{MATERIALS AND METHODS}

\section{Experiment I}

In total, 20,160 fertile eggs were used. Half of the eggs were laid by Cobb 500 breeders at the beginning of the laying period ( 31 weeks of age) and the other half derived from Cobb 500 breeders at the end of the laying period (52weeks of age).

In the hatchery, a completely randomized experimental design in a $4 \times 2$ factorial arrangement (in-ovo vaccination of embryos on 16,17, 18, or 19 days of incubation, and breeder age -31 and 52 weeks), totaling eight treatments with 15 replicates 
Fernandes JIM, Prokoski K, Oliveira BC, Oro CS, Oro PJ, Fernandes NLM
Evaluation of Incubation Yield, Vaccine Response, and Performance of Broilers Submitted to In-Ovo Vaccination at Different Embryonic Ages
168 eggs each. Each incubator was considered as an experimental unit, where four trays of 42 eggs were set (168 eggs $\times 15$ replicates $=2520$ eggs/treatment). All eggs were incubated on the same day in a similar single-stage incubation system.

Eggs were submitted to the in-ovo vaccination on days $16,17,18$, or 19 of incubation, after which, they were immediately transferred to the hatcher. The same vaccination procedures and vaccine strains and doses routinely utilized in the hatchery were applied. The vaccination program included vaccines against infectious bursal disease (IBD), fowlpox, and Marek's disease.

At hatch, on day 21 of incubation, chicks were counted, and the number of hatched chicks was subtracted from the total number of incubated eggs to calculate hatchability (\%). Unviable chicks culled due to several causes (small size, death, body abnormalities, navel infection, wet down, etc.) were counted. The quality of the viable chicks was then scored (1-10) according to the criteria of the Pasgarscore, considering reflex, navel, legs, beak, and abdomen (Boerjan, 2002).

Non-hatched eggs were submitted to embryodiagnosis, and their mortality classified according to embryonic age (0 to 3,4 to 10,11 to 17 , and 18 to 21 days of incubation).

\section{Experiment II}

A number of 960 one-d-old male chicks derived from each of the eight treatments applied experiment I were distributed in four replicate of 30 birds each.

Chicks were housed in an air-conditioned broiler house (15-m long x 12-m wide) divided into 36 pens measuring $3.75-\mathrm{m}^{2}$. The house was equipped with containing evaporative pads and hoods. Water and a commercial feed were provided ad libitum, according to a three-phase feeding program (starter, grower, and finisher).

Chicks and feeds were weighed at 7, 21, and 42 days of age for the evaluation of live performance (feed intake, weight gain, and feed conversion ratio).

On days 1, 7, and 21, serum samples were collected from two birds per replicate, totaling eight birds/ treatment for the titration of vaccine antibodies. Infectious bursal disease titers were determined using a commercial ELISA (Enzyme Linked Immune Sorbent Assay) kit from Idexx® Laboratory. However, commercial kits are still not available for the titration of Marek's disease and fowlpox antibodies. Thus, an indirect immune-enzymatic assay was standardized, using the vaccine strains as antigens.
For the standardization of the ELISA test, samples of commercial vaccines were submitted to cell disruption by centrifugation and freezing/thawing cycles. The samples were then submitted to another centrifugation (14000 $\mathrm{g}$ for $10 \mathrm{~min}$ ) in order to separate cellular debris. The remaining pellet was re-suspended in $600 \mu \mathrm{L}$ phosphate buffer solution (PBS) to prepare the antigen solution. The protein concentration of this solution was determined according to the method of Bradford (1976) method. The solutions were diluted in $0.05 \mathrm{M}$ carbonate bufferto adjust the protein solution to $1000 \mathrm{ng}$ and added to a flat-bottomwell. For well-plate adsorption, serum samples were diluted at 1:100, 1:200, and 1:400; in addition, for the immune-enzymatic conjugate, the dilutions were $1: 5000 ; 1: 10000 ;$ and 1:20000. After all the tests, the best serum dilution was determined as 1:200, while 1:20000 was the best dilution for the conjugate. The substrate tetramethylbenzidine (TMB) was used for well-late reading. The absorbance was measured at a wave length of $450 \mathrm{~nm}$ in the ELISA reader (Anthos 2010 -Biochrom $\AA)$.

The effect of days of incubation and breeder age and their interactions were submitted to two-way analysis of variance, using the GLM procedure of SAS (SAS Institute, 2004). Linear and quadratic effects were studied in the model by polynomial contrasts. Embryodiagnosis, hatchability, and inviable chick counts did not present normal distribution and were analyzed by the GENMOD procedure of SAS.

\section{RESULTS AND DISCUSSION}

A good understanding of factors that interact and influence the application of in-ovo vaccines is essential to optimize the routine utilization this technology in a hatchery. This study evaluated the effect of breederage, which directly influences embryo size and chick body weight, and of in-ovo vaccination at different embryonic ages in a commercial hatchery. The results are presented in Tables 1, 2, 3, 4, and 5 .

As shown in Table 1 and Figure 1,embryonic age at the time of in-ovo vaccination had a quadratic effect on hatchability $(p<0.05)$. According to the regression equation, the highest hatchability was obtained with vaccination on day 18.5 of incubation, independently of breeder age $\left(\hat{\mathrm{Y}}=\left(\mathrm{e}^{-33.9887+4.0468 \mathrm{x}-0.1091 \times 2}\right) /\left(1+\mathrm{e}^{-33.9887+4.0468 \mathrm{x}-}\right.\right.$ $0.10912 \times 2)$ ). When breeder ages were compared, the eggs of 31-wk-old breeders presented higher hatchability $(p<0.05)$ than those of 52 -wk-old breeders. Eggs vaccinated in-ovo on day 16 day of incubation presented lower $(p<0.05)$ hatchability, independently 
Fernandes JIM, Prokoski K, Oliveira BC, Oro CS, Oro PJ, Fernandes NLM

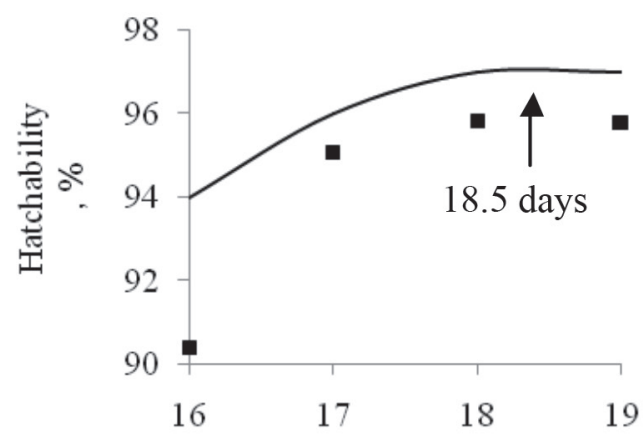

In-ovo vaccination, days

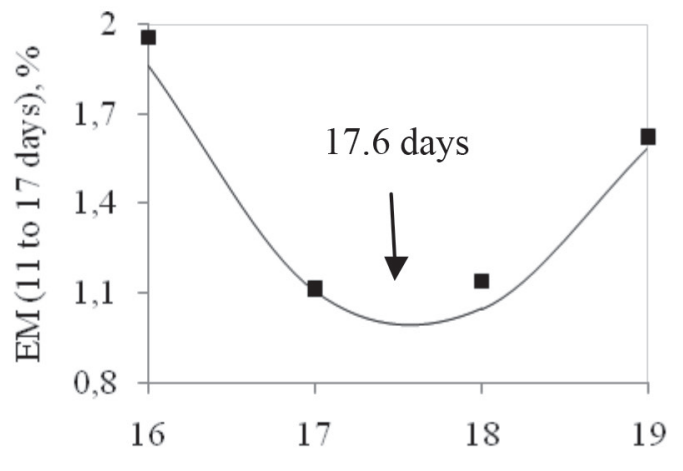

In-ovo vaccination, days

Figure 1 - Hatchability and embryonic mortality between 11 and 17 days of incubationaccording to breeder age and embryonic age on the day of in-ovo vaccination.

of breeder age. This reduction in hatchability was $4.68 \%$ when hatchings from vaccinated eggs on day 16 were compared with that of the other evaluated ages of embryo development.

It is important to emphasize that this result can also be influenced by the transfer of eggs from the incubator to the hatcher. The lower limit (17.5 days) is normally related to the period the yolk sac is starting to enter the abdomen and the head of the bird is positioned under the right wing. In order to determine the correct time for in-ovo injection to achieve maximum hatchability and good immune response against diseases, the

Table 1 - Hatchability, culling percentage, and chick quality score, as a function of breeder age and embryonic age on the day of in-ovo vaccination.

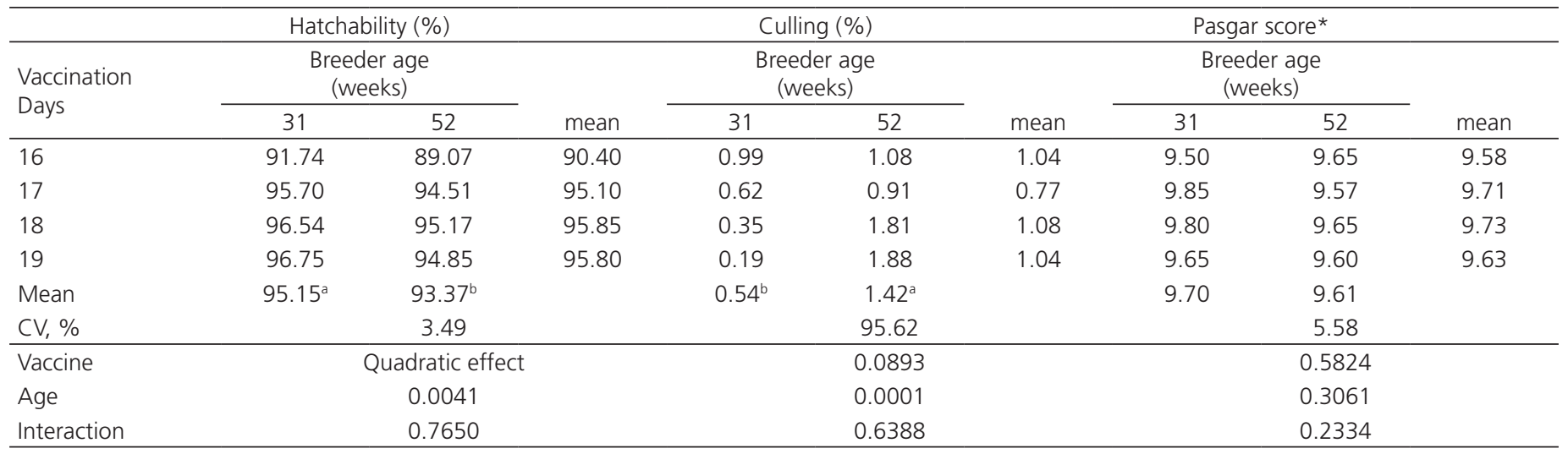

* chick quality score is expressed as Pasgar-score units (1-10).

$a, b$ - Means followed by different lowercase letters in the same row are different, as a function of breeder age.

Table 2 - Embryo diagnosis (mortality, \%) of set eggs according to breeder age and embryonic age on the day of in-ovo vaccination.

\begin{tabular}{|c|c|c|c|c|c|c|c|c|c|c|c|c|}
\hline \multirow{3}{*}{$\begin{array}{l}\text { Vaccination } \\
\text { Days }\end{array}$} & \multicolumn{2}{|c|}{0 to 3 days } & \multicolumn{4}{|c|}{4 to 10 days } & \multicolumn{2}{|c|}{11 to 17 days } & \multicolumn{4}{|c|}{18 to 21 days } \\
\hline & \multicolumn{2}{|c|}{$\begin{array}{c}\text { Breeder age } \\
\text { (weeks) }\end{array}$} & \multirow[b]{2}{*}{ mean } & \multicolumn{2}{|c|}{$\begin{array}{c}\text { Breeder age } \\
\text { (weeks) }\end{array}$} & \multirow[b]{2}{*}{ mean } & \multicolumn{2}{|c|}{$\begin{array}{c}\text { Breeder age } \\
\text { (weeks) }\end{array}$} & \multirow[b]{2}{*}{ mean } & \multicolumn{2}{|c|}{$\begin{array}{c}\text { Breeder age } \\
\text { (weeks) }\end{array}$} & \multirow[b]{2}{*}{ mean } \\
\hline & 31 & 52 & & 31 & 52 & & 31 & 52 & & 31 & 52 & \\
\hline 16 & 3.19 & 1.10 & 2.14 & 0.58 & 1.33 & 0.95 & 1.49 & 2.44 & 1.96 & 2.11 & 0.81 & 1.46 \\
\hline 17 & 2.91 & 1.60 & 2.25 & 0.94 & 1.23 & 1.08 & 0.46 & 1.76 & 1.11 & 2.22 & 0.95 & 1.59 \\
\hline 18 & 2.83 & 0.97 & 1.90 & 1.28 & 0.98 & 1.13 & 0.51 & 1.76 & 1.14 & 0.85 & 0.42 & 0.63 \\
\hline 19 & 3.30 & 0.90 & 2.10 & 0.64 & 0.95 & 0.80 & 1.60 & 1.64 & 1.62 & 2.15 & 0.51 & 1.33 \\
\hline Mean & $3.05^{a}$ & $1.15^{b}$ & & 0.86 & 1.13 & & $1.01^{b}$ & $1.91^{\mathrm{a}}$ & & $1.83^{\mathrm{a}}$ & $0.68^{b}$ & \\
\hline$C V, \%$ & & 54.61 & & & 87.49 & & & 89.24 & & & 71.58 & \\
\hline Vaccine & & 0.7283 & & & 0.1021 & & & Quadratic & & & 0.0870 & \\
\hline Age & & 0.0001 & & & 0.1022 & & & 0.0003 & & & 0.0001 & \\
\hline Interaction & & 0.1145 & & & 0.2084 & & & 0.4532 & & & 0.3444 & \\
\hline
\end{tabular}

a, b - Means followed by different lowercase letters in the same row are different, as a function of breeder age. 
Table 3 - Fowlpox titers (ELISA absorbance test) in the serum of broilers, according to breeder age and embryonic age on the day of in-ovo vaccination.

\begin{tabular}{|c|c|c|c|c|c|c|c|c|c|}
\hline \multirow{3}{*}{$\begin{array}{l}\text { Vaccination } \\
\text { Days }\end{array}$} & \multicolumn{2}{|c|}{1 day of age } & \multirow[b]{3}{*}{ mean } & \multirow{2}{*}{\multicolumn{2}{|c|}{$\begin{array}{c}7 \text { days of age } \\
\text { Breeder age } \\
\text { (weeks) }\end{array}$}} & \multicolumn{4}{|c|}{21 days of age } \\
\hline & \multicolumn{2}{|c|}{$\begin{array}{l}\text { Breeder age } \\
\text { (weeks) }\end{array}$} & & & & \multirow[b]{2}{*}{ mean } & \multicolumn{2}{|c|}{$\begin{array}{l}\text { Breeder age } \\
\text { (weeks) }\end{array}$} & \multirow[b]{2}{*}{ mean } \\
\hline & 31 & 52 & & 31 & 52 & & 31 & 52 & \\
\hline 16 & 0.205 & 0.219 & 0.212 & 0.065 & 0.081 & 0.073 & 0.048 & 0.075 & 0.062 \\
\hline 17 & 0.285 & 0.391 & 0.338 & 0.099 & 0.144 & 0.121 & 0.049 & 0.059 & 0.054 \\
\hline 18 & 0.237 & 0.424 & 0.331 & 0.089 & 0.076 & 0.082 & 0.076 & 0.045 & 0.061 \\
\hline 19 & 0.277 & 0.404 & 0.341 & 0.124 & 0.099 & 0.112 & 0.069 & 0.108 & 0.089 \\
\hline Mean & 0.250 & 0.360 & & 0.094 & 0.100 & & 0.061 & 0.072 & \\
\hline$C V, \%$ & & 52.30 & & & 62.48 & & & 62.39 & \\
\hline Vaccine & & 0.3296 & & & 0.2778 & & & 0.6876 & \\
\hline Age & & 0.0681 & & & 0.7108 & & & 0.7221 & \\
\hline Interaction & & 0.7559 & & & 0.8205 & & & 0.2936 & \\
\hline
\end{tabular}

Table 4 - Infectious bursal disease titers (ELISA absorbance test) in the serum of broilers, according to breeder age and embryonic age on the day of in-ovo vaccination

\begin{tabular}{|c|c|c|c|c|c|c|c|c|c|}
\hline \multirow{3}{*}{$\begin{array}{l}\text { Vaccination } \\
\text { Days }\end{array}$} & \multicolumn{2}{|c|}{1 day of age } & \multicolumn{3}{|c|}{7 days of age } & \multicolumn{4}{|c|}{21 days of age } \\
\hline & \multicolumn{2}{|c|}{$\begin{array}{c}\text { Breeder age } \\
\text { (weeks) }\end{array}$} & \multirow[b]{2}{*}{ mean } & \multicolumn{2}{|c|}{$\begin{array}{l}\text { Breeder age } \\
\text { (weeks) }\end{array}$} & \multirow[b]{2}{*}{ mean } & \multicolumn{2}{|c|}{$\begin{array}{l}\text { Breeder age } \\
\text { (weeks) }\end{array}$} & \multirow[b]{2}{*}{ Mean } \\
\hline & 31 & 52 & & 31 & 52 & & 31 & 52 & \\
\hline 16 & 0.665 & 0.695 & 0.680 & 0.358 & 0.494 & 0.426 & 0.111 & 0.124 & 0.117 \\
\hline 17 & 0.769 & 0.744 & 0.757 & 0.409 & 0.436 & 0.423 & 0.112 & 0.129 & 0.121 \\
\hline 18 & 0.801 & 0.753 & 0.777 & 0.384 & 0.417 & 0.396 & 0.121 & 0.136 & 0.129 \\
\hline 19 & 0.785 & 0.626 & 0.705 & 0.326 & 0.429 & 0.377 & 0.132 & 0.140 & 0.135 \\
\hline Mean & 0.755 & 0.704 & & $0.369^{b}$ & $0.447^{a}$ & & 0.119 & 0.132 & \\
\hline$C V, \%$ & & 24.58 & & & 37.18 & & & 23.60 & \\
\hline Vaccine & & 0.6885 & & & 0.7924 & & & 0.2069 & \\
\hline Age & & 0.4332 & & & 0.0504 & & & 0.3615 & \\
\hline Interaction & & 0.7588 & & & 0.7000 & & & 0.9382 & \\
\hline
\end{tabular}

a, b - Means followed by different lowercase letters in the same row are different, as a function of breeder age.

Table 5 - Marek's disease titers (ELISA absorbance test) in the serum of broilers, according to breeder age and embryonic age on the day of in-ovo vaccination.

\begin{tabular}{|c|c|c|c|c|c|c|c|c|c|}
\hline \multirow{3}{*}{$\begin{array}{l}\text { Vaccination } \\
\text { Days }\end{array}$} & \multicolumn{2}{|c|}{1 day of age } & & \multicolumn{2}{|c|}{7 days of age } & \multicolumn{4}{|c|}{21 days of age } \\
\hline & \multicolumn{2}{|c|}{$\begin{array}{l}\text { Breeder age } \\
\text { (weeks) }\end{array}$} & \multirow[b]{2}{*}{ mean } & \multicolumn{2}{|c|}{$\begin{array}{l}\text { Breeder age } \\
\text { (weeks) }\end{array}$} & \multirow[b]{2}{*}{ mean } & \multicolumn{2}{|c|}{$\begin{array}{l}\text { Breeder age } \\
\text { (weeks) }\end{array}$} & \multirow[b]{2}{*}{ mean } \\
\hline & 31 & 52 & & 31 & 52 & & 31 & 52 & \\
\hline 16 & 0.672 & 0.522 & 0.597 & 0.688 & 0.634 & 0.661 & $0.455^{\mathrm{A}}$ & $0.330^{A B}$ & 0.393 \\
\hline 17 & 0.615 & 0.428 & 0.522 & 0.750 & 0.728 & 0.739 & $0.497^{A}$ & $0.214^{B}$ & 0.355 \\
\hline 18 & 0.655 & 0.803 & 0.729 & 0.711 & 0.731 & 0.721 & $0.386^{A}$ & $0.389^{A B}$ & 0.387 \\
\hline 19 & 0.569 & 0.548 & 0.558 & 0.740 & 0.718 & 0.729 & $0.208^{B}$ & $0.461^{A}$ & 0.334 \\
\hline Mean & $0.627^{a}$ & $0.575^{b}$ & & 0.723 & 0.703 & & 0.386 & 0.348 & \\
\hline$C V, \%$ & & 23.74 & & & 15.13 & & & 31.38 & \\
\hline Vaccine & & 0.3334 & & & 0.4824 & & & 0.2572 & \\
\hline Age & & 0.0502 & & & 0.2114 & & & 0.5677 & \\
\hline Interaction & & 0.1317 & & & 0.8508 & & & 0.0001 & \\
\hline
\end{tabular}

a, b - Means followed by different lowercase letters in the same row are different, as a function of breeder age.

$A, B$ - Means followed by different uppercase letters in the same column are different as a function of vaccination days.

physiological characteristics of the embryo may be more important than the number of hours of incubation. Undeniably, studies aiming to evaluating the interaction between embryo age at vaccination and egg transfer are needed to clarify this question.
The hatchability of eggs transferred on day 18 of incubation was, on average, $1.4 \%$ higher than those transferred on day 17. However, when eggs were vaccinated and transferred at the same age, the difference in hatchability was $1.73 \%$. Ricks et al. 
Fernandes JIM, Prokoski K, Oliveira BC, Oro CS, Oro PJ, Fernandes NLM
Evaluation of Incubation Yield, Vaccine Response, and Performance of Broilers Submitted to In-Ovo Vaccination at Different Embryonic Ages
(1999) considered that the decrease in hatchability may be due to egg transfer rather than to egg injection. It is suggested that the $0.33 \%$ lower hatchability due to vaccination may be compensated by relocating hatchery labor from Sundays and holidays to working days.

When vaccination cannot be performed on day 18 , another possibility is to vaccinate on day 17.5 days of incubation or in the night before the embryos reach 18 days of age. This management practice allowed reducing hatching losses from 2.20 to $0.97 \%$ when vaccination was performed on days 18 and 17 , respectively. Ricks et al. (1999) concluded however, that these results can vary according to the season, breeder age and flock, and incubation system.

On the other hand, when vaccinating around 19 days of incubation, the injection may be made directly into the either in the amnion or the right breast area, because the embryo is more mature. Injecting the embryo's body is considered normal and acceptable; however, penetration of the needle in another location can result in lack of vaccine efficacy or damage to the embryos. Wakenell et al. (2002) found that a MD vaccine injected in the air cell provided no protection; in the allantoic fluid, $28.3 \%$ protection; in the amniotic fluid, $94.4 \%$ protection; in the embryo body, $93.9 \%$ protection. Therefore, an economic analysis to evaluate whether hatching losses when anticipating or delaying embryo age at vaccination compensate the costs of labor on Sundays and holidays.

The percentage of cullingdue to different causes was greater $(p<0.05)$ in chicks from older breeders, independently of embryo age at vaccination, which in turn, had no effect on this parameter.

Chick quality, expressed in terms of Pasgar scores, wasnot significantly different $(p>0.05)$ among treatments (Table 1).

Embryodiagnosis (Table 2) showed that mortality was higher between 0 and 3 days and 18 and 21 days of incubation $(p<0.05)$ in eggs from 21 -wk-old breeders, and between 11 and 17 days on incubation in those from 52-wk-old breeders, independently of day of in-ovo vaccination. There was a quadratic effect $(p<0.05)$ of age at vaccination age on embryo mortality (Figure 1). According to the regression equation, vaccination performed on day 17.6 resulted in the lowest mortality $\left(\hat{\mathrm{Y}}=\left(\mathrm{e}^{69.65-8.4296 x+0.2393 \times 2}\right) /\left(1+\mathrm{e}^{69.65-}\right.\right.$ $8.4296 \times+0.2393 \times 2))$. Vaccine injury was not observed in chicks as a result of embryonic age.

Okwor et al. (2014) showed the in-ovo vaccination of 13-d-old embryonated eggs resulted in higher embryonic mortality compared vaccination of 18-dayold embryonated eggs. According Williams (2005), the preferred time or 'window' for safely injecting the egg is from day 17 and 12-14 hours of incubation to day 19 and 2-4 hours of incubation, with time 'zero' being normal egg set time. That author also emphasized that if injection is done too early (before day 17.5), it may damage the embryo or support structures within the egg (too invasive), or it may be overwhelmed by high microbial challenge during hatch.

Antibody titers against IBD and fowlpoxmeasured in day-old chicks were not influenced ( $p>0.05)$ by breeder age or day of in-ovo vaccination (Tables 3 and 4). Ricks et al. (1999) mentioned that multiple vaccines, such as IBD and Marek's disease, can be jointly administered in-ovo and do not interfere with each other. On the other hand, higher antibody titers against Marek's disease were observed in the day-old offspring of 31-wk-old breeders relative to 52-wkold breeders (Table5). At 21 days of age, there was a significant interaction $(p<0.05)$ between breeder age and in-ovo vaccination day for Marek's disease antibody titrations. In the offspring of 31-wk-old breeders, similar antibody titers were observed in chicks vaccinated on days 16,17 , or 18 of incubation, where as those vaccinated on day 19 of incubation presented lower titers compared with those vaccinated on the other days. The antibody titers of 21-d-old chickens from 52-wk-old breeders were different only between those vaccinated on days 17 and 19 of incubation, with lower titers determined in those vaccinated on day 17 compared with day 19 .

Maternal antibodies may affect the effectiveness of embryonic vaccination against Marek's disease (Sharma \& Graham,1982). If chicks are vaccinated when maternal antibody titers are still high, the vaccine is not able to override them, resulting in lower efficiency of vaccination. This was confirmed in the present study, where the day-old offspring of older breeders, which usually are subjected to a more intense vaccination program, presented lower antibody titers compared with the offspring of younger breeders.

According to Comte \& Borne (2003), in-ovo vaccination against Marek's disease after 18 days of incubation establishes earlier protection than vaccinations on the first day of life because the vaccine takes eight days to become effective. In the present experiment, higher antibody titers were observed in 7-d-old chicks compared with to those detected on the first day of life. 
According to Sharma (1984), vaccination against Marek's disease performed on days 17 and 18 of incubation, did not impairthe immune response or predisposed chicks to the onset of disease lesions. According to this author, from this age, the embryo is able to support virus replication.

In the present study, there was an interaction between embryo age and breeder age for vaccination against Marek's disease. The antibody titers of the offspring of young breeders decreased when vaccinated on day 19 of incubation compared with the other vaccination days. However, no antibody titer pattern as a function of vaccination day was observed in the offspring of old breeders. At 21 days of age, maternal immunity is already decreased and the chick relies on its own vaccine titers. The significant interaction between breeder age and in-ovo vaccination days detected only at 21 days of age needs to be further better investigated in commercial flocks, since the immune response to the vaccine may be influenced by agents present in the environment.

Okwor et al. (2014) highlighted that there is a fast decrease in antibody titers starting from 21 days of life when a chick is vaccinated on the first day of life; however, in groups vaccinated on day 18 of incubation, the vaccine titers were maintained until 35 days. Therefore, we recommend monitoring vaccine titers under commercial conditions and compare them with historic immune data of the company, as well as to investigate the causes of vaccine failure in flocks vaccinated at ages different from those currently practiced in the hatchery.

One of the essential requirements of in-ovo vaccination is to provide the same amount of vaccine consistently to the same location inside the egg and at the same time. The vaccine must be administered in the amniotic fluid or subcutaneously into the embryo to elicit the best immune response. Vaccines delivered in the amniotic fluid on days $18 / 19$ are quickly distributed in the upper respiratory tract, gut, and bursa, which are key sites for the development of immunity against diseases (Villalobos, 2012). At this age, only part of the maternal antibodies present in the egg yolk is absorbed by the embryo, while total immunity develops only after a few days post-hatch. When a live vaccine is given to the embryo during this 'window', the virus is able to replicate without too much interference from maternal antibodies and thus trigger a good immune response; at the same time, the embryo has enough maternallyderived immunity to protect it from developing disease as a result of vaccination (Villalobos, 2012). Thus, it is expected that chicks that develop an early immune response are protected against diseases and present good growth performance.

Table 6 shows the performance results of the chicks between 1 to 7 days of age. There was no effect $(p>0.05)$ of the embryonic age at in-ovo vaccination on the performance of chicks in the first week of life. However, chicks of 52-wk-old breeders presented higher weight gain and feed intake $(p<0.05)$ than chicks of 31 -wk-old breeders. Hatching weight is closely related with egg weight, because it influences mass of the residual yolk sac that the chick retains at hatch (Joseph \& Moran Jr., 2005). In the current experiment, the body weight of day-old chicks of 52-wk-old breeders was higher compared with those of 31-wk-old breeders (48.7 vs. $42.3 \mathrm{~g}$, respectively).

This was reflected in the performance results of the chickens obtained from 1 to 21 days of age. Higher weight gain and better feed conversion ratio $(p<0.05)$ were achieved by the offspring of older breeders

Table 6 - Performance of broilers between 1 and 7 days of age according to breeder age and embryonic age on the day of in-ovo vaccination

\begin{tabular}{|c|c|c|c|c|c|c|c|c|c|}
\hline \multirow{3}{*}{ Vaccination Days } & \multicolumn{2}{|c|}{ Weight gain, $g$} & \multicolumn{3}{|c|}{ Feed conversion } & \multicolumn{4}{|c|}{ Feed intake, $\mathrm{g}$} \\
\hline & \multicolumn{2}{|c|}{ Breeder age (weeks) } & \multirow[b]{2}{*}{ mean } & \multicolumn{2}{|c|}{ Breeder age (weeks) } & \multirow[b]{2}{*}{ mean } & \multicolumn{2}{|c|}{ Breeder age (weeks) } & \multirow[b]{2}{*}{ mean } \\
\hline & 31 & 52 & & 31 & 52 & & 31 & 52 & \\
\hline 16 & 141.29 & 157.21 & 149.25 & 1.08 & 1.06 & 1.07 & 152.21 & 165.81 & 159.01 \\
\hline 17 & 139.75 & 156.39 & 148.07 & 1.09 & 1.08 & 1.09 & 152.94 & 167.84 & 160.39 \\
\hline 18 & 143.33 & 155.68 & 149.51 & 1.07 & 1.10 & 1.09 & 152.94 & 171.69 & 162.32 \\
\hline 19 & 140.65 & 151.75 & 146.20 & 1.09 & 1.11 & 1.10 & 152.94 & 166.91 & 159.93 \\
\hline Mean & $141.98^{b}$ & $155.26^{a}$ & & 1.08 & 1.09 & & $153.11^{b}$ & $168.06^{\mathrm{a}}$ & \\
\hline$C V, \%$ & & 3.364 & & & 2.510 & & & 3.181 & \\
\hline Vaccine & & 0.2812 & & & 0.2864 & & & 0.8040 & \\
\hline Age & & 0.0001 & & & 0.1127 & & & 0.0001 & \\
\hline Interaction & & 0.6951 & & & 0.3530 & & & 0.7836 & \\
\hline
\end{tabular}

a, b - Means followed by different lowercase letters in the same row are different, as a function of breeder age 
relative to younger breeders (Table 7 ). Considering the performance during the total evaluated period, from 1 to 42 days (Table 8), no significant effect ( $p>0.05$ ) of breeder age or day of in-ovo vaccination was observed on any studied performance parameter.

It is important to highlight that the transfer of eggs from the incubator to the hatcher at the ages when vaccinations occurred may have a stronger impact on the results than vaccination itself. Therefore, the effects of egg transfer with no interference of vaccination should be investigated.

The lack of any adverse effects of vaccination performed between 16 and 19 days of incubation on chick quality chicks and broiler performance at slaughter age shows that it is possible to perform vaccinations at any of these ages. However, as previously discussed, broilers were reared in an experimental poultry barn, and because of the good hygiene and environmental conditions and the adequate management practice applied, natural challenges were minimum. On the other hand, under commercial conditions, environmental quality may be poor due to inadequate cleaning and disinfection of the facilities, high rearing density, and other factors that may pose a greater challenge to the birds and allow the establishment of pathogens, potentially causing disease.

In-ovo vaccination has several advantages over the conventional vaccination methods, including neonatal resistance, administration of uniform dose of virus and better protection, administration of vaccine in eggs en masse, reduction of labor costs and limited farmer's involvement (Okwor et al., 2014). Thus, the use of adequate in-ovo vaccination programs requires, in addition of knowledge onthe entire production process, to take into account the specific needs of each hatchery. Constant updates on the vaccine programs applied in each region is extremely important, as well as the compliance with the current regulations, consideration of possible factors that can affect vaccination, knowledge on the specific characteristics of each vaccine, and particularly the establishment of an adequate vaccination program according to the health status of the flock.

Table 7 - Performance of broilers of 1 to 21 days of age according to breeder age and embryonic age on the day of in-ovo vaccination

\begin{tabular}{|c|c|c|c|c|c|c|c|c|c|}
\hline \multirow{3}{*}{$\begin{array}{l}\text { Vaccination } \\
\text { Days }\end{array}$} & \multicolumn{2}{|c|}{ Weight gain, g } & \multicolumn{3}{|c|}{ Feed conversion } & \multicolumn{4}{|c|}{ Feed intake, $\mathrm{g}$} \\
\hline & \multicolumn{2}{|c|}{$\begin{array}{c}\text { Breeder age } \\
\text { (weeks) }\end{array}$} & \multirow[b]{2}{*}{ mean } & \multicolumn{2}{|c|}{$\begin{array}{c}\text { Breeder age } \\
\text { (weeks) }\end{array}$} & \multirow[b]{2}{*}{ mean } & \multicolumn{2}{|c|}{$\begin{array}{l}\text { Breeder age } \\
\text { (weeks) }\end{array}$} & \multirow[b]{2}{*}{ mean } \\
\hline & 31 & 52 & & 31 & 52 & & 31 & 52 & \\
\hline 16 & 931.59 & 976.17 & 953.88 & 1.33 & 1.29 & 1.31 & 1169.85 & 1192.28 & 1181.07 \\
\hline 17 & 934.02 & 985.69 & 959.86 & 1.32 & 1.30 & 1.31 & 1170.96 & 1211.75 & 1191.35 \\
\hline 18 & 936.04 & 978.10 & 957.07 & 1.33 & 1.28 & 1.31 & 1182.35 & 1190.81 & 1186.58 \\
\hline 19 & 932.34 & 998.49 & 965.42 & 1.35 & 1.31 & 1.33 & 1193.38 & 1204.41 & 1198.90 \\
\hline Mean & $934.81^{b}$ & $984.61^{a}$ & & $1.33^{a}$ & $1.30^{b}$ & & 1179.33 & 1199.81 & \\
\hline$C V, \%$ & & 2.52 & & & 1.19 & & & 2.78 & \\
\hline Vaccine & & 0.9465 & & & 0.5433 & & & 0.5755 & \\
\hline Age & & 0.0001 & & & 0.0011 & & & 0.0990 & \\
\hline Interaction & & 0.7902 & & & 0.7300 & & & 0.9374 & \\
\hline
\end{tabular}

Table 8 - Performance of broilers of 1 to 42 days of age according to breeder age and embryonic age on the day of in-ovo vaccination

\begin{tabular}{|c|c|c|c|c|c|c|c|c|c|}
\hline \multirow{3}{*}{$\begin{array}{l}\text { Vaccination } \\
\text { Days }\end{array}$} & \multicolumn{2}{|c|}{ Weight gain, g } & \multirow[b]{3}{*}{ mean } & \multirow{2}{*}{\multicolumn{2}{|c|}{$\begin{array}{c}\text { Feed conversion } \\
\text { Breeder age } \\
\text { (weeks) }\end{array}$}} & \multirow{2}{*}{\multicolumn{3}{|c|}{$\begin{array}{c}\text { Feed intake, g } \\
\text { Breeder age } \\
\text { (weeks) }\end{array}$}} & \multirow[b]{3}{*}{ mean } \\
\hline & \multicolumn{2}{|c|}{$\begin{array}{c}\text { Breeder age } \\
\text { (weeks) }\end{array}$} & & & & & & & \\
\hline & 31 & 52 & & 31 & 52 & mean & 31 & 52 & \\
\hline 16 & 3154.07 & 3159.77 & 3156.92 & 1.54 & 1.54 & 1.54 & 4564.44 & 4513.45 & 4538.94 \\
\hline 17 & 3163.45 & 3121.30 & 3142.37 & 1.55 & 1.56 & 1.56 & 4579.55 & 4533.60 & 4556.58 \\
\hline 18 & 3186.64 & 3227.43 & 3207.03 & 1.54 & 1.54 & 1.54 & 4613.21 & 4612.47 & 4612.84 \\
\hline 19 & 3150.28 & 3252.41 & 3201.35 & 1.54 & 1.54 & 1.54 & 4520.34 & 4704.40 & 4612.37 \\
\hline Mean & 3161.91 & 3190.23 & & 1.54 & 1.55 & & 4562.33 & 4590.98 & \\
\hline$C V, \%$ & & 2.73 & & & 1.62 & & & 2.29 & \\
\hline Vaccine & & 0.6952 & & & 0.9415 & & & 0.4897 & \\
\hline Age & & 0.1938 & & & 0.5287 & & & 0.2797 & \\
\hline Interaction & & 0.8178 & & & 0.7416 & & & 0.2895 & \\
\hline
\end{tabular}


Fernandes JIM, Prokoski K, Oliveira BC, Oro CS, Oro PJ, Fernandes NLM

\section{CONCLUSION}

The results of the present study showed that inovo vaccination, independently of breeder age, can be performed between days 17.6 and 18.5 of incubation without causing any hatchability or chick quality losses. In-ovo vaccination on day 16 of incubation reduces hatchability in $4.68 \%$ compared with the other vaccination days, independently of breeder age. However, we recommend evaluating the effect of egg transfer only for better understanding this result.

The vaccine response of the offspring and the performance of broilers at the slaughter age were not influenced by in-ovo vaccination day or by breeder age. Hatchery losses when the vaccination needs to be performed on day 16 of incubation needs to be considered in the decision-making process by poultry companies.

\section{REFERENCES}

Abudabos A. The Effect of broiler breeder strain and parent flock age on hatchability and fertile hatchability. International Journal of Poultry Science 2010;9:231-235

Avakian A, Wakenell PS, Bryan T, Schaeffer JL, Williams CJ, Whitfill CE. In ovo administration of Marek's disease vaccine: Importance of vaccine deposition site in the fertile egg. Proceedings of $51^{\circ}$ Western Poultry Disease Conference; 2002; Puerto Vallarta. México: Veterinary Software Publishing O'Fallon.

Avisite. Pintos de corte sofreram expressivo refluxo em novembro/14 [cited 2015 Out 22]. 2014. Available from: http://www.avisite.com.br/ economia/index.php?acao=producaopintos.

Berchieri JrA, Bolis DA. Vacinações e aplicações de produtos intra-ovo. In: MACARI, M.; GONZALES, E, editores. Manejo da incubação.Campinas: FACTA; 2003. p.267-283.

Boerjan M. Programs for single stage incubation and chick quality. Poultry Avian Biology Review. 2002;13:237-238.

Bradford M. A dye binding assay for protein. Analytical Biochemistry $1976 ; 72: 248-254$.
Comte S, Borne P. Vacinas e vacinação na produção avícola. São Paulo: Ceva Santa Animale; 2003. 140 p.

Edens FW. Aplicações da Tecnologia In-ovo em Sanidade Avícola. Anais da Conferência Apinco de Ciência e Tecnologia Avícola; 1999; Campinas, São Paulo. Brasil.

Joseph NS, Moran Jr ET. Effect of flock age and post emergent holding in the hatcher on broiler live performance and further-processing yield. Journal Applied Poultry Research 2005;14:512-520.

Negash T, Al-garib SO, Gruqays E. Comparison of in-ovo and post-hatch vaccination with particular reference to infectious bursal disease. A review. The Veterinary Quarterly 2004;26:76-87.

Okwor GO, El-Yuguda A, Baba SS. Profile of maternally derived antibody in broiler chicks and in-ovo vaccination of chick embryo against newcastle disease. World Journal of Vaccines 2014;4:72-80.

Oliveira J. Zoetis lança equipamento de vacinação in ovo [cited 2015 Nov 11]. Agrolink. Notícia; 2013. Available from: http://agrolink.com.br/ noticias/zoetis-lanca-equipamento-de-vacinacao-in-ovo_179353.html.

Ricks CA, Avakian A, Bryan T, Gildersleve R, Haddad E, Ilich R, et al. In-ovo vaccination technology. Advances in Veterinary Medicine 1999;41:495515 .

SAS Institute. SAS user's guide: statistics. Cary; 2002

Sharma JM, Lee LF, Wakenell PS. Comparative viral, immunologic, and pathologic responses of chickens inoculated with herpesvirus of turkeys as embryos or at hatch. American Journal of Veterinary Research 1984;45(8):1619-1623.

Villalobos T. In ovo technology driving hatchery modernisation [cited 2015 Set 12]. 2012. Available from: http://www.worldpoultry.net/Breeders/ Incubation/2012/4/In-ovo-technology-driving-hatchery-modernisation WP010206W.

Wakenell PS, Bryan T, Schaeffer J, Avakian A, Williams C, Whitfill C. Effect of in ovo vaccine delivery route on herpes virus of turkeys/sb-1 - Efficacy and viraemia. Avian Diseases 2002;46:274-280.

Williams CJ. In-ovo vaccination and chick quality. International Hatchery Practice 2005;19:7-13.

Williams CJ, Hopkins BA. Field evaluation of the accuracy of vaccine deposition by two different commercially available in ovo injection systems. Poultry Science 2011;90:223-226.

Williams CJ, Zedek AS. Comparative field evaluations of in-ovo applied technology. Poultry Science 2010;89:189-193. 
